\title{
UPAYA MENINGKATKAN KEPERCAYAAN ORGANISASI MELALUI PERBAIKAN PERILAKU PEMIMPIN DAN KEADILAN ORGANISASI
}

\author{
Yuyun Elizabeth Patras \\ Rais Hidayat \\ Universitas Pakuan \\ yuyunpatras64@gmail.com
}

\begin{abstract}
Organizational trust is essential so that members of the organization can continue to contribute to the progress of the organization. The purpose of this research is to find out how far the variables of leadership behavior and organizational justice on improving organizational trust. The research method used is associative quantitative causal method, and the testing hypothesis research using path analysis technique. The population in this study is 707 permanent lecturers who have the National Lecturer Number (NIDN). The sample is 130 respondents. The instrument test was conducted to 30 respondents outside the sample. The findings of this research indicate that the higher the leadership behavior in directing subordinates, providing support to subordinates; increase member participation in achieving organizational goals, and rewarding the achievers, the higher the trust in the organization. Other findings show that the higher the organization's justice the higher the trust in the organization.
\end{abstract}

Keywords: Organizational Trust, Organizational Justice, Leadership Behavior.

\begin{abstract}
Abstrak: Kepercayaan pada organisasi sangat penting agar agar anggota organisasi dapat terus berkontribusi pada kemajuan organisasi. Tujuan penelitian ini untuk melihat sejauhmana variabel perilaku kepemimpinan dan keadilan organisasi dalam meningkatkan kepercayaan organisasi. Metode penelitian yang digunakan adalah metode kuantitatif asosiatif kausal dengan pengujian hipotesis penelitian menggunakan teknik path analysis. Populasi dalam penelitian ini 707 dosen tetap yang memiliki Nomor Induk Dosen Nasional (NIDN). Sampel penelitian sebanyak 130 responden. Ujicoba instrumen dilakukan kepada 30 responden diluar sampel. Temuan penelitian ini menunjukkan bahwa semakin tinggi perilaku kepemimpinan dalam mengarahkan bawahan, pemberian dukungan kepada bawahan; meningkatkan partisipasi anggota dalam pencapaian tujuan organisasi, dan pemberian penghargaan pada yang berprestasi, maka semakin tinggi kepercayaan pada organisasi. Temuan lainya menunjukan bahwa semakin tinggi keadilan organisasi maka semakin tinggi pula kepercayaan pada organisasi.
\end{abstract}

Kata kunci: kepercayaan organisasi, keadilan organisasi, perilaku kepemimpinan. 
Kepercayaan (trust) merupakan suatu keyakinan penuh dari seseorang terhadap orang lain atau terhadap sesuatu sehingga orang tersebut menyerahkan semua harapan dan keinginan, bahkan hidupnya kepada yang dipercayainya. Kepercayaan merupakan unsur paling penting dalam organisasi. Melalui sikap saling mempercayai maka tim kerja dalam organisasi akan mendapat kesempatan untuk mewujudkan tujuan organisasi dengan lebih baik. Goetsch dan Davis menyatakan bahwa dalam sebuah organisasi hal yang paling penting adalah kepercayaan antara rekan kerja. (2013:55)

Kepercayaan dalam organisasi yang tinggi dapat membangun hubungan baik bagi sesama kelompok dalam tim karena jika anggota tim percaya dengan anggota tim lainnya, maka perilaku antar sesama tim akan membaik pula (George dan Jones:2012). Adanya saling percaya di antara anggota organisasi akan tercipta kondisi yang baik untuk pertukaran informasi sehingga meningkatkan kinerja organisasi (Eko Widodo, 2015:204).

Kepercayaan terhadap organisasi sebagai pelumas yang memungkinkan organisasi untuk bekerja dengan efektif. Organisasi dengan tingkat kepercayaan yang tinggi memiliki tenaga kerja lebih produktif, moral anggota organisasi yang lebih baik dan pergantian anggota organisasi yang rendah (Bennis dalam Hitch, 2012: 4).

Beberapa hal yang berkaitan dengan kepercayaan pada organisasi yang tinggi sebagai berikut: (1) informasi dibagi secara terbuka; (2) kesalahan ditoleransi dan didorong sebagai cara belajar; (3) budaya Inovatif dan kreatif; (4) orang-orang setia kepada mereka yang tidak hadir; (5) orangorang berbicara jujur dan menghadapi masalah-masalah yang nyata; 6) ada beberapa "komunikasi nyata dan kolaborasi yang nyata"; (7) tidak ada "pertemuan setelah pertemuan"; 8) transparansi adalah nilai yang dipraktekkan; ( 9) Orang-orang jujur dan otentik; 10) ada akuntabilitas; 11) ada vitalitas dan energy teraba dan dapat merasakan momentum positif (Covey dan Merril, 2008: 237)

Kepercayaan sangat diperlukan baik kepercayaan antar anggota organisasi maupun anggota organisasi terhadap pemimpin ataupun kepercayaan terhadap organisasi. Keuntungan dari kepercayaan anggota organisasi terhadap organisasi antara lain: (1) kepercayaan mendorong kemampuan mengambil resiko, (2) kepercayaan memfasilitasi pertukaran informasi, (3) kepercayaan dari kelompok lebih efektif. Kepercayaan juga meningkatkan produktifitas kerja (Robbins dan Judge, 2009: 424)

Berdasarkan arti penting kepercayaan pada organisasi, maka dipandang perlu untuk melakukan penelitian tentang hakikat kepercayaan pada organisasi, memahami faktor-falkor yang dapat meningkatkan kepercayaan pada organisasi dan upayaupaya untuk meningkatkan kepercayaan pada organisasi. Penelitian ini difokuskan pada faktor yang dapat meningkatkan kepercayaan pada organisasi melalui perbaikan variabel perilaku kepemimpinan dan keadilan organisasi.

\section{Kepercayaan pada Organisasi}

Kepercayaan merupakan sebuah nilai yang lahir dari hubungan interpersonal yang diperoleh secara lambat tetapi akan hilang atau rusak dengan cepat jika terjadi pelanggaran kecil terhadap kepercayaan (Pinder, 2008:353). Kepercayaan berhubungan dengan harapan bahwa orang yang kita percaya tidak akan mengambil keuntungan dari kita (Lussier, 2008:303)

Robbins dan Judge (2012:421) memandang kepercayaan sebagai kondisi psikologis yang terjadi ketika seseorang setuju untuk percaya kepada orang lain walaupun berada dalam keadaan ketidakpastian dengan bagaimana keadaan tersebut akan memberikan hasil positif. Colquitt, Lepine, dan Wesson (2009: 424) menyatakan bahwa kepercayaan merupakan kehendak untuk menyerahkan diri kepada sebuah otoritas berdasarkan harapan yang positif mengenai kehendak dan tindakan otoritas tersebut.

Kepercayaan terbangun karena adanya integritas, kompetensi, konsistensi dan keterbukaan dari organisasi. Lussier berpendapat bahwa untuk meningkatkan integritas dapat dilakukan dengan cara mengatakan yang sebenarnya, menjaga komitmen dan bersifat adil (Lussier, 2008:305-306) 
Kreitner dan Angelo Kinicki (2010:316) menyatakan bahwa kepercayaan dapat dibangun melalui: 1) komunikasi yaitu anggota dan pemilik perusahaan mengetahui kebijakan dan keputusan dan menyiapkan umpan balik yang tepat, 2) dorongan yaitu adanya coaching, mentoring, consultation, untuk anggota tim, 3) rasa hormat yaitu manajer memberikan keputusan secara adil, 4) keadilan yaitu dengan segera memberikan balasan dan pengakuan kepada yang berhak menerima, membuat penilaian kinerja secara objektif dan tidak merugikan, 5) prediktabel yaitu konsisten dan bisa diprediksi, 6) kompetensi yaitu mununjukkan keahlian, sikap dan keterampilan dalam bekerja.

Robin dan Judge (2012:424) menyatakan bahwa kepercayaan pada organisasi harus dikembangkan. Salah satu jenis kepercayaan yaitu kepercayaan prophencity mengacu kepada bagaimana seorang anggota organisasi secara khusus mempercayai pemimpinnya. Bagi seorang pemimpin untuk dapat dipercaya butuh waktu yang sangat panjang. Para pemimpin harus menunjukan integrity, beneviolence, dan ability mereka dalam organisasi sehingga para anggota organisasi mempercayai mereka. Kepercayaan tidak akan pernah kembali secara penuh, walaupun sudah ada permintaan maaf, janji, atau perubahan perilaku secara konsisten (Robin dan Judge, 2012:423).

Goetsch dan Davis

menyatakan bahwa dalam berkomunikasi, penyampaian dan penerimaan pesan butuh saling percaya. Dalam hubungan antar interpersonal kepercayaan merupakan dasar yang paling fundamental. Orang yang saling mempercayai akan dapat saling bekerja sama dalam keadaan apapun.

Berdasarkan paparan konsep di atas dapat disintesiskan bahwa kepercayaan pada organisasi adalah kehendak anggota organisasi untuk menyerahkan diri terhadap otoritas organisasi dengan harapan organisasi mewujudkan harapan positif anggota organisasi.

\section{Perilaku Kepemimpinan}

Lussier menyatakan bahwa pemimpin yang dapat memimpin secara efektif adalah perilaku pemimpin itu sendiri (Lussier, 2008:284) Slocum dan Hellriegel (2007:170) menyatakan bahwa perilaku kepemimpinan berfokus pada apa yang dilakukan pemimpin dan bagaimana pemimpin melakukannya. Hughes, Ginnett, dan Curphy menyatakan perilaku kepemimpinan adalah apa yang dilakukan pemimpin terhadap pengikutnya sehingga ia berhasil membentuk sebuah tim atau mencapai tujuan. Owens menyatakan bahwa perilaku kepemimpinan adalah apa yang dilakukan seorang pemimpin untuk menolong bawahannya dalam meningkatkan kinerja (Hughes, Ginnett, dan Curphy, 2009: 136)

Yukl (2010:103) menyatakan bahwa perilaku kepemimpinan berfokus mempelajari jenis-jenis perilaku kepemimpinan yang paling memengaruhi kepuasan dan kinerja bawahan. Daft (2008:43) mempertegas bahwa siapapun selama melakukan perilaku yang sesuai dengan kepemimpinan maka orang tersebut akan menjadi pemimpin yang sukses. Ini jelas bahwa perilaku atau tindakan pemimpin sangat berpengaruh dalam menggerakan organisasi. Patras (2017:3) mendefinisikan perilaku kepemimpinan adalah tindakan yang dilakukan pemimpin agar tercapi kesuksesan organisasi. Hidayat (2017:4) perilaku kepemimpinan adalah tindakan yang dilakukan pemimpin ditujukan agar dosen berhasil mengerjakan tugas, puas, berdaya.

Perilaku pemimpin yang efektif memengaruhi bawahan menurut McShane dan Glinov (2000) terdiri dari 4 hal, yaitu : (1) directive, yaitu kejelasan tujuan, proses, dan standar kinerja yang diinginkan oleh pemimpin, (2) supportive, yaitu kepemimpinan yang berpusat pada orang, misalnya bersahabat, menyenangkan, menghormati bawahan, dan penuh perhatian pada bawahan, (3) participative, yaitu memberikan kesempatan pada bawahan untuk terlibat dalam mengambil keputusan, meminta masukan bawahan atas pekerjaan dan meminta ide-ide bawahan untuk kemajuan pekerjaan, dan (4) achievementoriented, yaitu mendorong bawahan untuk mencapai pretasi tertinggi dalam pekerjaan.

Perilaku pemimpin yang efektif menurut Luthans (2011:426) yaitu: (1) directive leadership: pemimpin yang dapat mengarahkan bawahan secara khusus (2) supportive leadership: pemimpin memiliki sifat bersahabat bagi bawahan dan memiliki 
bisa menyatu dengan bawahan (3) participative leadership pemimpin yang meminta masukan dari bawahan sebelum pemimpin mengambil keputusan, (4) achievement-oriented leadership membuat tujuan yang menantang untuk dicapai oleh bawahan..

Perilaku pemimpin yang efektif menurut Goetsch dan Davis (2013) dilakukan dengaan cara sebagai berikut: (1) aligning personel with the vision (mengikat anggota organisasi dengan visi), (2) provide a sense of direction (menyediakan anggota organisasi arahan yang jelas), (3) commucating effective and often (komunikasi efektif dan sering), (4) empowering (melakukan pemberdayaan), dan (5) training and mentoring (pelatihan dan pemantauan).

Berdasarkan penjelasan di atas dapat disintesiskan bahwa perilaku kepemimpinan adalah tindakan memengaruhi yang dilakukan pemimpin agar tercapai kesuksesan dalam organisasi.

\section{Keadilan Organisasi}

Keadilan organisasi adalah persepsi anggota organisasi tentang seberapa adil organisasi memperlakukan anggota organisasi di tempat mereka bekerja (Griffin dan Morhead, 2007:385). Kreitner dan Kinicki (2010) yang didukung oleh Schermerhorn et al. (2011) bahwa keadilan organisasi mengarah kepada sejauh mana keadilan dan keseimbangan organisasi diberlakukan bagi anggota organisasi dalam organisasi tersebut.

George and Jones (2012) keadilan organisasi merupakan konsep yang memotret persepsi anggota organisasi tentang keadilan dalam organisasi tempat mereka bekerja. Keadilan organisasi berkaitan dengan persepsi seorang anggota organisasi atas derajat keadilan yang diberikan organisasi (Gibson et al., 2006:154). Anggota organisasi akan merasa diperlakukan secara adil jika mereka meyakini reward dan cara pendistribusian reward didistribusikan dengan adil kepada mereka (Robins dan Judge, 2013:256). Luthans (2011:173) mendefinisikan keadilan organisasi sebagai keseluruhan dari iklim keadilan dalam organisasi yang terdiri dari keadilan distributif, prosedural, interaksional.
Keadilan organisasi dibentuk dari beberapa dimensi atau domain. McShane dan Glinov (2000) yang diperkuat Gibson et al.(2006) membagi keadilan organisasi menjadi dua dimensi yaitu keadilan distributif dan keadilan prosedural. Schemerhorn et al. (2010: 117) membagi keadilan organisasi terdiri dari 3 domain yaitu: keadilan distributif, keadilan procedural; dan keadilan interaksional.

George and Jones (2012) menayatakan bahwa keadilan organisasi terdiri dari 4 dimensi yaitu: distributif justice, procedural justice, interpersonal justice, dan informational justice. Griffin (2007) mendukung konsep menegaskan bahwa keadilan organisasi terbagi atas empat dimensi yaitu keadilan distributif, keadilan prosedural, keadilan interpersonal dan keadilan informasional. Colquitt, Lepine, Wesson (2009) menegaskan konsep di atas bahwa keadilan pimpinan ketika atasan mengambil keputusan (justice) meliputi empat dimensi yaitu keadilan distributif, prosedural, interpersonal dan informasional.

Colquitt, Lepine, Wesson (2009) menyatakan bahwa keadilan distributif mengacu pada keadilan yang menyangkut dengan pengambilan keputusan penghasilan contohnya: gaji, promosi, penghargaan, evaluasi, penilaian pekerjaan yang dilakukan berdasarkan norma-norma kebaikan dan keadilan. Keadilan prosedural mengacu pada proses pengambilan keputusan tentang proses pendistribusian income. Keadilan interpersonal yang merefleksikan persepsi keadilan yang berhubungan dengan perlakuan penguasa terhadap anggota organisasi. Colquit, Lepine, dan Wesson (2009) menyatakan bahwa keadilan interpersonal ditekankan dalam 2 aturan khusus yaitu: aturan penghargaan yang meliputi memperlakukan anggota organisasi dengan baik dan benar dan aturan memperlakukan anggota organisasi dengan sopan dan penuh penghargaan. Keadilan informasional berhubungan dengan komunikasi yang dilakukan manajer terhadap anggota organisasi.

Berdasarkan paparan di atas dapat disintesiskan bahwa keadilan organisasi adalah persepsi anggota organisasi tentang bagaimana anggota organisasi diperlakukan secara adil di organisasi tempat bekerja. 


\section{METODE}

Penelitian ini bertujuan untuk
menganalisis dan mendeskripsikan
pengaruh dari variabel perilaku
kepemimpinan dan keadilan organisasi
terhadap kepercayaan pada organisasi.
Penelitian dilaksanakan tahun 2015 di 3
universitas swasta di Bogor, Indonesia.

Metode penelitian yang digunakan adalah metode kuantitatif asosiatif kausal dengan pengujian hipotesis penelitian menggunakan teknik path analysis. Populasi dalam penelitian ini 707 dosen tetap yang memiliki Nomor Induk Dosen Nasional (NIDN). Sampel penelitian sebanyak 130. Ujicoba instrumen dilakukan kepada 30 responden diluar sampel. Validitas instrumen penelitian diuji melalui teknik korelasi Product Moment Pearson. Uji reliabilitas instrumen penelitian menggunakan perhitungan Alpha Cronbach. Sedangkan analisis data menggunakan statitik inferensial dengan menggunakan uji analisis varian dan regresi.

Pada penelitian ini definisi operasional kepercayaan pada organisasi adalah kehendak dosen untuk menyerahkan diri terhadap otoritas universitas dengan harapan universitas dapat mewujudkan harapan positif dosen yang pengukurannya dilakukan terhadap dosen melalui instrumen angket yang berisi pernyataan-pernyataan mengenai kepercayaan pada universitas yang disusun berdasarkan (1) integritas universitas dengan indikator kejujuran dan kebenaran, (2) kompetensi universitas dengan indikator teknik, pengetahuan interpersonal dan keahlian, (3) konsistensi universitas dengan indikator reliabilitas, kemampuan memprediksi sesuatu, dan baik dalam menghadapi segala sesuatu, (4) loyalitas universitas dengan indikator kemauan untuk melindungi orang lain secara fisik dan emosional, (5) keterbukaan universitas dengan indikator kemauan untuk berbagi ide - ide dan informasi

Definisi operasional perilaku kepemimpinan adalah tindakan memengaruhi yang dilakukan pemimpin agar tercapai kesuksesan dalam organisasi yang pengukurannya dilakukan terhadap dosen melalui instrumen angket yang berisi pernyataan-pernyataan mengenai perilaku kepemimpinan ketua program studi yang disusun berdasarkan aspek-aspek: pengarahan dengan indikator kejelasan tujuan, proses, dan standar kinerja, (2) pemberian dukungan dengan indikator bersahabat, menyenangkan, menghormati dosen, dan penuh perhatian pada dosen, (3) berpartisipasi dengan indikator pelibatan dosen dalam pengambilan keputusan, meminta masukan pada dosen, pemberian penghargaan pada prestasi dengan indikator mendorong bawahan berprestasi.

Definisi keadilan organisasi adalah persepsi dosen tentang bagaimana dia diperlakukan secara adil di universitas yang pengukurannya dilakukan oleh dosen melalui instrumen angket yang yang berisi pernyataan-pernyataan mengenai keadilan organisasi yang disusun berdasarkan indikator sebagai berikut: (1) keadilan distributif, (2) keadilan prosedural, (3) keadilan interaksional, (4) keadilan informasional.

Adapun hipotesis dalam penelitian yang akan diuji yaitu: (1) Apakah perilaku kepemimpinan berpengaruh langsung positif terhadap kepercayaan pada organisasi; (2) Apakah keadilan organisasi berpengaruh langsung positif terhadap kepercayaan organisasi?

\section{HASIL}

Penelitian ini menjadikan variabel kepercayaan pada organisasi $\left(X_{3}\right)$ sebagai variabel endogen atau variabel terikat, sedangkan variabel perilaku kepemimpinan $\left(X_{1}\right)$, keadilan organisasi $\left(X_{2}\right)$ sebagai eksogen atau variabel bebas. Berdasarkan strukturnya terdapat dua koefisien jalur, yaitu: koefisien jalur $\mathrm{X}_{1}$ dan $\mathrm{X} 2$ atas $\mathrm{X}_{3}$. Selanjutnya bentuk jalur pengaruh tersebut melahirkan suatu persamaan struktur prediktif dengan formulasi : $X_{3}=p_{31} X_{1}+p_{32} X_{2}$

Berdasarkan hasil perhitungan regresi didapatkan koefisien jalur sebagai berikut $p_{31}=0,187, p_{32}=0,246$. Dengan demikian bentuk persamaan struktur prediktif menjadi $X_{3}=0,187 X_{1}+0,246 X_{2}$. Berdasarkan persamaan tersebut jika diasumsikan pengaruh variabel lain tetap, maka dapat disimpulkan bahwa setiap kenaikan satu unit perilaku kepemimpinan $\left(X_{1}\right)$ akan menaikan 0,187 unit kepercayaan pada organisasi $\left(X_{3}\right)$, ditambah dengan setiap kenaikan keadilan organisasi $\left(X_{2}\right)$ akan menaikan 
0,246 unit kepercayaan pada organisasi $\left(\mathrm{X}_{3}\right)$.

Pengaruh langsung variabel perilaku kepemimpinan dan keadilan organisasi secara bersama-sama terhadap kepercayaan pada organisasi sama dengan $R_{3.12}^{2}=(0,345)^{2}=0,119$. Artinya variasi kepercayaan pada organisasi ditentukan oleh variasi perilaku kepemimpinan kaprodi dan keadilan organisasi secara bersamasama setara dengan $11,9 \%$. Visualisasi bentuk dan nilai koefisien pada masingmasing jalur terlihat dalam gambar 1 berikut:

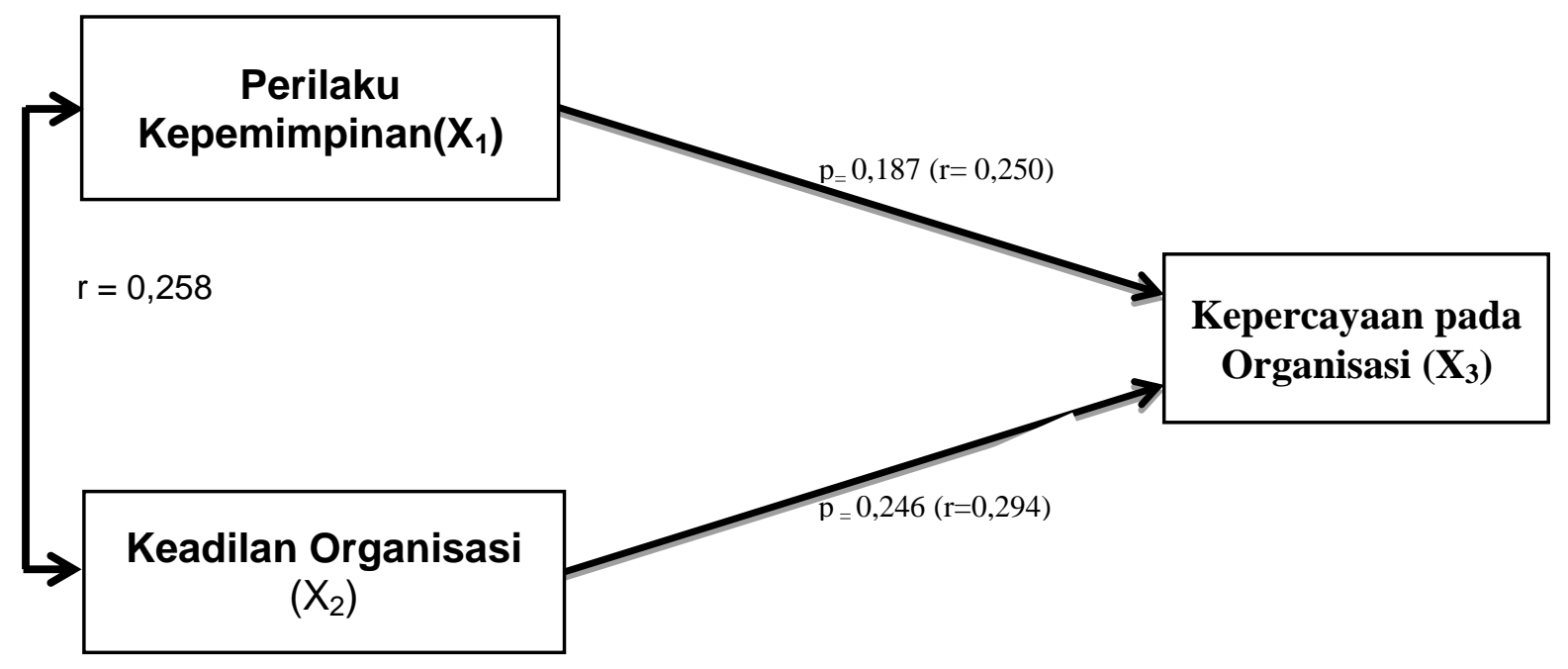

Gambar 1. Hasil Perhitungan Koefisien Jalur

Berdasarkan hasil uji-t diperoleh koefisien jalur $\rho_{31}=0,187$ dengan nilai $t_{\text {hitung }}$ $=2,164$ sedangkan nilai $t_{\text {tabel }}(\alpha=0,05)=$ 1,960. Fakta ini mengungkapkan bahwa $t_{\text {hitung }}>\mathrm{t}_{\text {tabel }}$ yang berarti $\mathrm{H}_{0}$ ditolak dan $\mathrm{H}_{1}$ diterima. Artinya koefisien jalur ini signifikan. Temuan ini dapat diinterpretasikan bahwa perilaku kepemimpinan berpengaruh langsung positif terhadap kepercayaan pada organisasi. Implikasinya adalah perilaku kepemimpinan yang efektif akan mengakibatkan peningkatan kepercayaan pada organisasi.

Berdasarkan hasil uji-t diperoleh koefisien jalur $\rho_{32}=0,246$ dengan nilai $t_{\text {hitung }}=$ 2,855 sedangkan nilai $t_{\text {tabel }}(\alpha=0,05)=1,960$. Fakta ini mengungkapkan bahwa $t_{\text {hitung }}>t_{\text {tabel }}$ yang berarti $\mathrm{H}_{0}$ ditolak dan $\mathrm{H}_{1}$ diterima. Artinya koefisien jalur ini signifikan. Temuan ini dapat diinterpretasikan bahwa keadilan organisasi berpengaruh langsung positif terhadap kepercayaan pada organisasi. Implikasinya adalah keadilan organisasi yang tinggi akan mengakibatkan peningkatan kepercayaan pada organisasi.

\section{PEMBAHASAN \\ Upaya Peningkatan Kepercayaan Melalui Kepemimpinan}

Penelitian ini menunjukkan bahwa erilaku kepemimpinan, khususnya perilaku kepemimpinan ketua program studi (Kaprodi) yang menjadi fokus dan lokus penelitian ini telah terbukti secara meyakinkan berpengaruh langsung positif terhadap kepercayaan pada organisasi. Ini berarti bahwa perilaku kepemimpinan yang efektif akan mengakibatkan peningkatan kepercayaan pada organisasi. Berarti pula bahwa perbaikan-perbaikan dari sisi perilaku kepemimpinan dapat menyebabkan kepercayaan anggota organisasi menjadi lebih tinggi.

Temuan penelitian ini sejalan dengan hasil penelitian Hartog, Shippers dan Koopman dalam Spector (2007: 334) bahwa kepemimpinan yang efektif dapat meningkatkan kepercayaan karyawan dan manajemen. Penelitian ini sejalan dengan pendapat Spector yang menyatakan bahwa kepemimpinan dapat mempengaruhi sikap, keyakinan, perilaku, dan perasaan orang lain. Kepemimpinan dapat dilakukan oleh bukan pemimpin, namun kemampuan 
mempengaruhi oleh seorang pemimpin jauh lebih hebat dibandingkan oleh yang bukan pemimpin (Yukl, 2008).

Berdasarkan penelitian ini peningkattan kepercayaan pada organisasi dapat dilakukan melalui peningkatan perilaku kepemimpinan melalui aktifitas sebagai berikut: mengarahkan bawahan; pemberian dukungan kepada bawahan; meningkatkan partisipasi dosen dalam pencapaian tujuan prodi; dan pemberian penghargaan pada yang berprestasi.

Mengarahkan bawahan dapat dilakukan dengan menetapkan target yang harus dicapai Prodi, menjelaskan tujuan Prodi disertai langkah-langkah mencapainya, mengevaluasi ketercapaian tujuan prodi secara terjadual, membuat proses pencapaian tujuan Prodi bersama dengan dosen, memfasilitasi sosialisasi aturan kerja kepada dosen, melakukan monitoring proses kerja secara terjadual, melakukan penilaian kinerja dosen berdasarkan standar kerja yang berlaku di Prodi, membuat dan mengimplementasikan standar kerja dosen secara transparan.

Pemberian dukungan kepada bawahan dapat dilakukan dengan cara sebagai berikut: memberikan bantuan kepada dosen yang mengalami kesulitan, menjaga rahasia pribadi dosen, menjadi tempat berkeluh kesah dosen, membuat suasana menjadi nyaman, memiliki selera humor yang tinggi, memberikan kebebasan kepada dosen untuk menggunakan berbagai metode dalam mengajar, memberi ucapan selamat hari raya pada dosen yang berbeda agama, menelpon dosen untuk mengingatkan jadual perkuliahan, melakukan kunjungan kepada dosen yang sakit, memberikan motivasi berprestasi kepada dosen, dan melakukan komunikasi dua arah dengan dosen.

Partisipasi dosen dalam pencapaian tujuan Prodi dapat dilakukan dengan melibatkan dosen untuk memberikan saran dalam pengambilan keputusan, meminta masukan dosen dalam pengembangan prodi, melibatkan dosen dalam rapat evaluasi Prodi secara terjadual, memanggil dosen secara pribadi untuk membicarakan pengembangan Prodi, menerima saran dari dosen, dan memberikan apresiasi kepada dosen yang memberikan ide terhadap pengembangan prodi.
Pemberian penghargaan pada dosen dapat dilakukan dengan mengadakan pemilihan dosen berprestasi secara periodik, memfasilitasi pengadaan buku-buku referensi terbaru, dan melengkapi akses informasi berupa koneksi jaringan internet secara memadai.

Perilaku kepemimpinan Kaprodi dalam membangun kepercayaan pada organisasi di prodi dapat dilakukan Kaprodi antara lain Kaprodi menjadi garda terdepan dalam memengaruhi prodi agar integritas prodi, kompetensi prodi, konsistensi prodi, loyalitas prodi, dan keterbukaan prodi tetap terjaga. Jika Perilaku kepemimpinan Kaprodi sudah menunjukkan hal demikian maka kepercayaan dosen pada oraganisasi akan tumbuh, antara lain ditandai dosen lebih berkehendak untuk menyerahkan diri terhadap otoritas prodi dan perilaku dosen akan lebih meningkat. Pengaruh perilaku kepemimpinan terhadap kepercayaan pada organisasi sejalan dengan model integratif (integrative model of organizational behavior) yang dikemukakan oleh Colquit, Lepine, dan Wesson (2009).

\section{Upaya Meningkatkan Kepercayaan Melalui Keadilan}

Berdasarkan hasil pengujian hipotesis menunjukkan bahwa Keadilan organisasi berpengaruh langsung positif terhadap kepercayaan pada organisasi. Hal ini terlihat dari nilai koefisien jalur yang diperoleh $\rho_{32}=$ 0,246 dengan nilai $t_{\text {hitung }}=2,855$ sedangkan nilai $t_{\text {tabel }}(\alpha=0,05)=1,960$. Fakta ini mengungkapkan bahwa $t_{\text {hitung }}>t_{\text {tabel }}$ yang berarti $\mathrm{H}_{0}$ ditolak dan $\mathrm{H}_{1}$ diterima bahwa koefisien jalur $\rho_{32}=0,246$ adalah signifikan pada taraf signifikansi $\alpha=0,05$. Dengan demikian telah teruji melalui penelitian ini bahwa keadilan organisasi berpengaruh langsung positif terhadap kepercayaan pada organisasi. Ini berarti peningkatan keadilan dalam organisasi dapat meningkatkan kepercayaan pada organisasi.

Hasil penelitian oleh Al-Abrow, Ardakani, Haroonic dan Moghaddam dengan judul The Relationship between Organizational Trust and Organizational Justice Components and Their Role in Job Involvement in Education (2013) menunjukkan bahwa keadilan distribusi dan prosedural berpengaruh positif dan kuat terhadap kepercayaan pada organisasi. 
Hasil penelitian Chan dan Mauborgne (2005) menunjukan adanya pengaruh keadilan organisasi terhadap kepercayaan pada organisasi. Hal ini menunjukkan betapa pentingnya proses keadilan dalam membentuk sikap dan perilaku individu. Secara emosional individu mengharapkan pengakuan terhadap keberadaan dirinya dan nilai bukan hanya sekedar sebagai pribadi atau sumber daya tetapi sebagai manusia. Setiap individu ingin diperlakukan dengan hormat, penuh penghargaan, layak dan hal ini harus diperhatikan oleh para pemimpin dimana mereka bekerja dalam proses keadilan dalam pekerjaan.

Berdasarkan penelitian ini peningkatan kepercayaan pada organisasi melalui keadilan organisasi dapat dilakukan dalam bentuk upaya perbaikan sebagai berikut: perbaikan keadilan distributive, perbaikan keadilan prosedural, perbaikan keadilan interpersonal, dan perbaikan keadilan informasional.

Perbaikan keadaan keadilan distributif dapat dilakukan dengan memperbaiki imbalan dosen, memberikan kesempatan kepada dosen untuk meningkatkan kualifikasi pendidikan mereka, memperbaiki sistem promosi kepada dosen, memberlakukan imbalan berdasarkan kinerja, memperbaiki sistem karir untuk dosen, memperbaiki sistem penjaminan mutu, berlaku adil dalam pemberian promosi kepada dosen, dan tidak memberikan imbalan atas dasar hubungan persahabatan.

Perbaikan keadilan prosedural dapat dilakukan sebagai berikut: memberlakukan aturan kenaikan gaji secara berkala, menilai kinerja oleh orang yang mengerti penilaian kinerja, penilain kinerja harus sudah sesuai dengan peraturan pemerintah yang terbaru, menggunakan aturan yang jelas dalam mekanisme pembagian imbal jasa pada dosen, dan melibatkan dosen dalam membuat sistem pemberian imbalan.

Perbaikan keadilan interpersonal dapat dilakukan sebagai beriku: menyiapkan kotak saran untuk menampung aspirasi dosen, memperlakukan dosen dengan hormat, merespospon dengan cepat keluh kesah dosen, menjaga hubungan antara prodi/universitas dengan dosen secara erat, menyiapkan makanan kecil bagi dosen, menghindari untuk memperlakukan dosen berdasarkan kedekatan pribadi, menyelenggarakan family gathering sekali dalam setahun, memberikan santunan bagi anggota keluarga dosen yang meninggal.

Perbaikan keadilan informasional dapat dilakungan sebagai berikut: sistem penilaian kinerja mudah diakses, menyediakan sarana untuk merespon pertanyaan-pertanyaan dosen tentang sistem pemberian imbalan, mengadakan workshop tentang sistem promosi secara berkala, memberikan informasi tentang seminar dan workshop untuk dosen, menginformasikan tentang kerjasama prodi/universitas dengan prodi/universitas dalam dan luar negeri, dan mensosialisasikan pemberitahuan dari DIKTI tentang beasiswa bagi dosen.

\section{KESIMPULAN}

Terdapat pengaruh langsung positif perilaku kepemimpinan terhadap kepercayaan pada organisasi. Artinya perilaku kepemimpinan yang efektif mengakibatkan peningkatan kepercayaan pada organisasi. Perilaku kepemimpinan yang efektif dapat dilihat dan dirasakan dari adanya tujuan, proses, dan standar kinerja, tinggginya pemberian dukungan yang bersahabat, menyenangkan, menghormati, dan penuh perhatian kepada para dosen, tingginya pelibatan dosen dalam pengambilan keputusan dan pemberian masukan untuk kemajuan prodi, dan tingginya pemberian penghargaan pada prestasi dosen. Perilaku kepemimpinan yang efektif di atas mengakibatkan kepercayaan pada organisasi meningkat dalam bentuk tingginya kepercayaan pada organisasi.

Terdapat pengaruh langsung positif keadilan organisasi terhadap kepercayaan pada organisasi. Artinya keadilan organisasi yang tinggi mengakibatkan peningkatan kepercayaan pada organisasi. Keadilan organisasi yang tinggi dipersepsikan dosen dalam bentuk persepsi dosen atas keadilan distributif, keadilan prosedural, keadilan interpersonal, dan keadilah informasional dalam organisasi. Persepsi dosen yang tinggi atas keadilan-keadilan di atas mengakibatkan peningkatan kepercayaan dosen pada organisasi meningkat. 


\section{DAFTAR RUJUKAN}

AL-Abrrow, Hadi A., Mohammad Shaker Ardakanib, (2013). Alireza haroonic and Hamidreza Moghaddam pourd The Relationship between Organizational Trust and Organizational Justice Components and Their Role in Job Involvement in Education, IJOMA International Journal of Management Academy.

Chan, W., Kim Renee Mauborgne (2005). Blue Ocean strategy. Boston: Harvard Business School Press.

Colquit, Jason A., Jeffrey A. Lepine, Michael J. Wesson (2009). Organizational Behavior. Improving Performance and Commitment in the Workplace. NewYork: McGraw-Hill.

Daft, Richard L (2008). The Leadership Experience. Singapore: Thomson South-Western

George, Jennifer M., Gareth R. Jones. (2012) Understanding and Managing Organizatioanl Behavior. Boston: Printice Hall.

Gibson, James L., John M. Ivancevich, James H. Donnelly, Jr, Robertk Konopaske (2006). Organizations, Behavior, Sructure and Proceses Boston: McGraw-Hill.

Goetsch, David L., Stanley Davis. (2013). Quality Management for Organizational Excellence, Introduction to Total Quality Management. Boston: Pearson.

Griffin, Rcky W., Gregory Moorhead. (2007) Organizational Behavior, Managing People and Organizatios. Boston: Houghton Mifflin Company.

Hidayat Rais. (2017). Perilaku Etis Dosen Dalam Perspektif Efikasi Diri, Kepemimpinan, Dan Komunikasi Interpersonal. PEDAGONAL, Jurnal IImiah Pendidikan. Vol 1 No 1.

Hughes, Richard L., Robert C. Ginnett, Gordon J. Curphy. (2009). Leadership, Enhancing the Lesson of Experience. Boston: McGraw-Hill.
John W. Slocum dan Don Hellriegel. (2007) Fundamental of Organizational Behavior. Ohio: Thomson SouthWesten.

Lussier, Robert N. (2008). Human Relations in Organization. Boston: McGraw-Hill.

Luthans, Fred. (2008) Orgnizational Behavior. New York: McGraw-Hill

McShane, Steven L. and Mary Ann Von Glinow. (2010). Organizational Behavior, Emerging Knowledge and Practice for Real World. New York: McGraw-Hill Irwin.

Patras, Yuyun Elizabeth. (2007). Pengaruh Perilaku Kepemimpinan, Keadilan Organisasi Dan Keterlibatan Kerja Terhadap Organizational Citizenzhip Behavior Dosen. PEDAGONAL. Jurnal IImiah Pendidikan. Vol 1 No 1.

Pinder, Craig C. (2008) Work Motivation In Organizational Behavior. New York: Psycology Press.

Robbins, Stephen P. dan Timothy A Judge. (2013) Organizational Behavior Fifteenth Edition. New Jersey: Prentice Hall.

Schermerhorn, John R., James G. Hunt, Ricard N. Osborn, Mary Uhl-Bien. (2010). Organizational Behavior. Danvers USA: John Wiley \& Sons, Inc.

Yukl, Gary. (2008) Leadership in Organization. New York: Pearson Educational Int. 